\title{
Nitric oxide signalling and antidepressant action revisited
}

\author{
Samia R. L. Joca ${ }^{1,2} \cdot$ Ariandra G. Sartim ${ }^{1}$ - Aline L. Roncalho ${ }^{1}$ - Cassiano F.A. Diniz ${ }^{3}$ - Gregers Wegener ${ }^{4}$ (D)
}

Received: 11 November 2018 / Accepted: 21 December 2018 / Published online: 16 January 2019

(C) The Author(s) 2019

\begin{abstract}
Studies about the pathogenesis of mood disorders have consistently shown that multiple factors, including genetic and environmental, play a crucial role on their development and neurobiology. Multiple pathological theories have been proposed, of which several ultimately affects or is a consequence of dysfunction in brain neuroplasticity and homeostatic mechanisms. However, current clinical available pharmacological intervention, which is predominantly monoamine-based, suffers from a partial and lacking response even after weeks of continuous treatment. These issues raise the need for better understanding of aetiologies and brain abnormalities in depression, as well as developing novel treatment strategies. Nitric oxide (NO) is a gaseous unconventional neurotransmitter, which regulates and governs several important physiological functions in the central nervous system, including processes, which can be associated with the development of mood disorders. This review will present general aspects of the NO system in depression, highlighting potential targets that may be utilized and further explored as novel therapeutic targets in the future pharmacotherapy of depression. In particular, the review will link the importance of neuroplasticity mechanisms governed by $\mathrm{NO}$ to a possible molecular basis for the antidepressant effects.
\end{abstract}

Keywords Depression $\cdot$ Nitric oxide $\cdot$ Antidepressants $\cdot$ Neuroplasticity $\cdot$ BDNF

\section{Introduction}

Depression is a severe psychiatric condition with a lifetime prevalence of ca. 20\% worldwide (Hasin et al. 2018; Kessler and Bromet 2013). Depression is associated to increased risk of all-cause mortality (Lasserre et al. 2016) and a reduced life expectancy of 7-14 years has been reported (Chang et al. 2011; Laursen et al. 2016). Depression is the leading cause of disability worldwide, responsible for $7.5 \%$ of years lived with disability and it contributes to $2.5 \%$ of the global burden of disease, corresponding to more than 70 million disabilityadjusted life years (DALYs) (Vos et al. 2017). Similarly, in a

Gregers Wegener

wegener@clin.au.dk

1 School of Pharmaceutical Sciences of Ribeirão Preto (FCFRP), University of Sao Paulo (USP), Sao Paulo, Brazil

2 Aarhus Institute of Advanced Studies (AIAS), Aarhus University, Aarhus, Denmark

3 School of Medicine of Ribeirão Preto (FMRP), University of Sao Paulo (USP), Sao Paulo, Brazil

4 Translational Neuropsychiatry Unit (TNU), Department of Clinical Medicine, Aarhus University, Aarhus, Denmark
European material, affective disorders are among the most costly diseases (110 billion Euro) and anxiety disorders among the most prevalent (Olesen and Leonardi 2003; Olesen et al. 2008; Wittchen et al. 2011). It has been estimated that the global economy loses about $\$ 1$ trillion every year in productivity due to depression and anxiety and that the appropriate treatment of depression would result in a large economic productivity gain of $\$ 230$ billion (Chisholm et al. 2016). Although research indicates that antidepressants are overall effective for treatment of depression (Cipriani et al. 2018), several weeks of treatment are required to achieve a significant mood-improving effect and a significant proportion of patients are partial or non-responders, which limit the success of the therapy for many patients. Since the introduction of the currently marketed antidepressant drugs in the 1950s to the 1980s, which all are based on monoaminergic pharmacological effects, there has been no major breakthrough in finding novel effective drug targets, despite considerable effort (Wegener and Rujescu 2013). Unfortunately, the pathogenesis and neurobiology of affective disorders is not well understood. Based on genetic and environmental factors, multiple hypotheses are proposed involving distinct pathways, for example neurotransmission (Caspi et al. 2003) and neurotrophic factors (Zhao et al. 2018). The present review will focus on the 
role of the atypical neurotransmitter nitric oxide (NO) in depression and (i) address general aspects of the NO system in depression, (ii) focus on drugs affecting NO production as putative therapeutic molecules and finally, (iii) highlight possible molecular mechanisms related to brain neuroplasticity.

\section{Basic principles of nitric oxide signalling in the brain}

Initial evidence indicating $\mathrm{NO}$ as a possible signalling molecule in the brain came from the seminal work by Garthwaite and colleagues (Garthwaite 2008; Garthwaite et al. 1988), showing that activation of $\mathrm{N}$-methyl-D-aspartate (NMDA) receptors by glutamate increased the release in a $\mathrm{Ca}^{2+}$ - dependent manner of a diffusible messenger, which was later shown to be NO. Today, it is well known that NO is formed on demand during its enzymatic conversion from L-arginine by the enzymes NO synthase (NOS), as reviewed by Guix and co-workers (Guix et al. 2005). Briefly, the three major isoforms of NOS are neuronal NOS (nNOS), endothelial NOS (eNOS) and inducible NOS (iNOS). nNOS and eNOS are $\mathrm{Ca}^{2}$-calmodulin-dependent enzymes constitutively expressed primarily in neurons and endothelial cells. However, iNOS has a high affinity for $\mathrm{Ca}^{2+}$-calmodulin, thus being usually active when expressed in the cell. Under basal conditions, iNOS levels are usually very low, requiring de novo synthesis triggered by immunological or inflammatory stimulation in macrophages, astrocytes, microglia and other cells, to produce significant amounts of NO (Amitai 2010).

Abundant evidence points to the fact that all three NOS isoforms are able to affect cell signalling in the brain, with nNOS representing the major source for NO synthesis, anchored in close proximity to NMDA receptors through postsynaptic proteins (Garthwaite 2008). However, additional stimuli can trigger or inhibit nNOS activation in response to increased intracellular calcium concentration, such as the activation of muscarinic (M1 or M3) (Borda et al. 1998), purinergic (P2R) receptors (Florenzano et al. 2008) and several receptors/transport proteins relevant for serotonergic neurotransmission (Chanrion et al. 2007; Hiroaki-Sato et al. 2014; Marcoli et al. 1997; Raiteri et al. 1991) (Fig. 1).

The main cellular target for NO is the enzyme soluble guanylyl cyclase (sGC), which upon activation catalyses the conversion of cyclic guanosine monophosphate (GTP) into cyclic guanosine monophosphate (cGMP). cGMP activates protein kinase $\mathrm{G}$ (PKG)-dependent signalling (Feil and Kleppisch 2008; Kleppisch and Feil 2009). Both nNOS and sGC are co-localized in several limbic brain regions, supporting the idea of an integrated NO-cGMP signalling system (Ding et al. 2004). In addition, NO can also nitrosylate many different proteins affecting their activity, with important consequences for neuronal signalling and neuroplasticity
(Jaffrey et al. 2001). A comprehensive overview of NOmediated mechanisms in the brain is beyond the scope of the present review and can be found elsewhere (Garthwaite 2008).

\section{Nitric oxide and depression}

Evidence from humans has not been consistent regarding nNOS expression and/or activity in post-mortem material from patients with major depression. In some studies, a reduced number of nNOS containing neurons in the paraventricular hypothalamic nucleus was observed (Bernstein et al. 2002; Bernstein et al. 1998) and a strong trend $(p<0.06)$ in decreased activity of the constitutive NOS was found in the prefrontal cortex (Xing et al. 2002) and locus coeruleus (Karolewicz et al. 2004) of patients with depression. In the brains from the Stanley Consortium, an increase in the CA1 hippocampal area nNOS immunoreactivity in depression and bipolar disorder has been reported (Oliveira et al. 2008). This highlights the complexity of NO neurochemistry in depression neurobiology, indicating that an imbalance rather than an overall increase or decrease in NOS activity seems to be related to the neurobiology of depression.

To understand the involvement of NO in depression, a number of studies have examined peripheral NO metabolism in major depression, however with rather mixed results. In a study of suicide attempters, increased $\mathrm{NO}$ metabolites $\left(\mathrm{NO}_{2}\right.$ and $\mathrm{NO}_{3}$ ) were observed (Kim et al. 2006; Lee et al. 2006), suggesting a dysfunctional peripheral nitrergic system. A similar finding was reported in drug-naïve depressive patients diagnosed according to DSM-IV (Suzuki et al. 2001) and in the same study, treatment with an antidepressant normalized the nitrite levels, in correlation with the clinical response (Suzuki et al. 2001). In another study of DSM-IV diagnosed depressed patients, there was no correlation between depressive symptoms and levels of nitrate but a significant effect of antidepressant treatment, lowering the nitrate levels was observed (Herken et al. 2007). In addition, there are some studies demonstrating involvement of NO in some but not all forms of IFN-alpha-induced depression (Suzuki et al. 2003). Importantly, measurement of nitrate in serum will only detect the overall nitrate pool and not potential clinically relevant subcompartments. This is exemplified in a study of depressed individuals showing a $73 \%$ decrease in nitrite content in the polymorphonuclear leukocytes (Srivastava et al. 2002). Since human polymorphonuclear leukocytes express neuron-like nNOS (Wallerath et al. 1997), this measure may be hypothesized to be more relevant than serum values.

Examinations on polymorphisms of NOS have contributed with mixed findings, although some evidence for a role of $\mathrm{NO}$ in depressive disorders seems to be present. In a populationbased association study investigating nNOS in unipolar depression, it was tested whether the nNOS C276T 


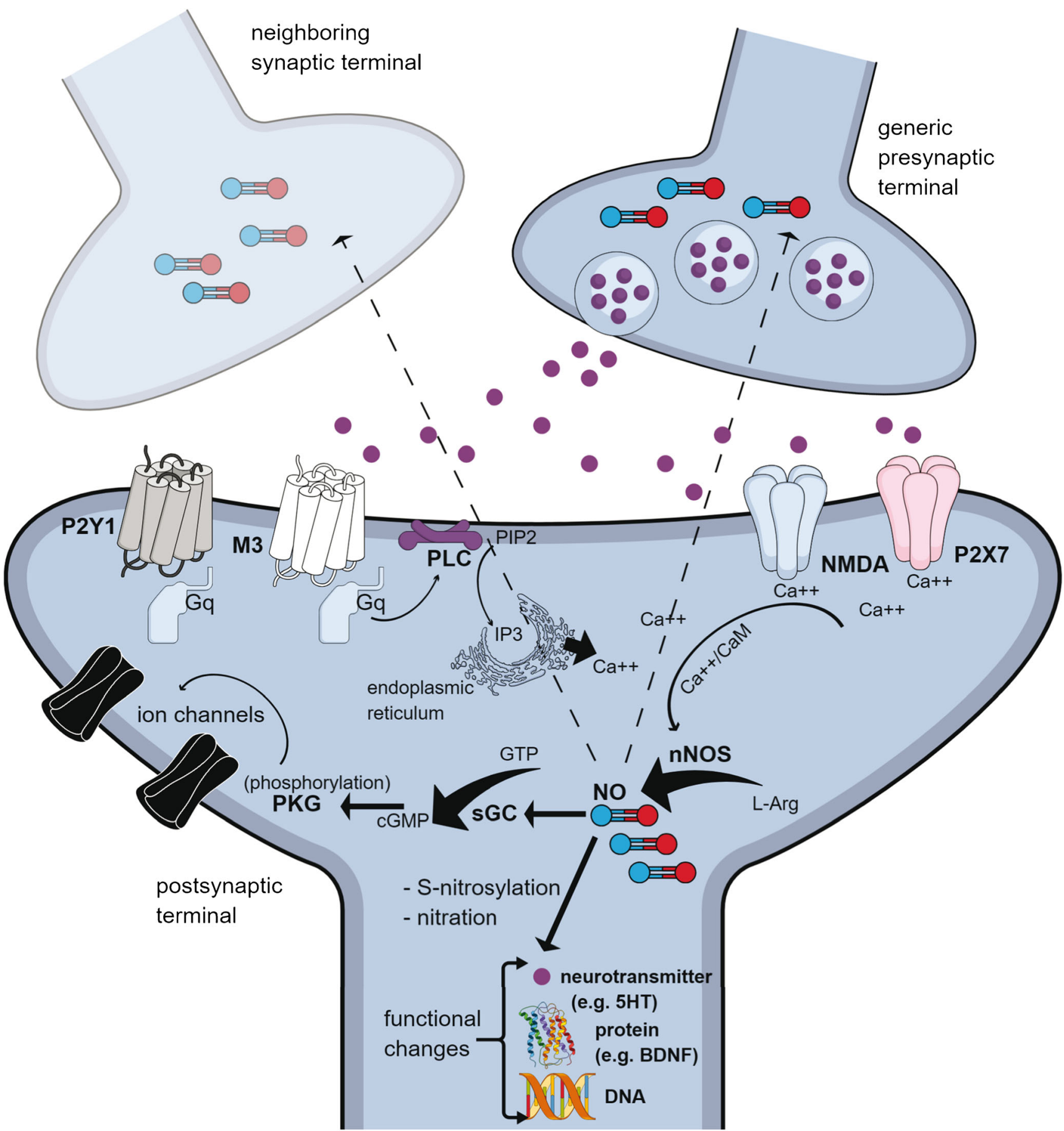

Fig. 1 Role of nNOS-derived NO in synaptic homeostasis. nNOSderived NO is released following glutamate activation of AMPA and NMDA receptors, with an influx of $\mathrm{Ca}^{2+}$ leading to the activation of nNOS. NO exerts various neuromodulatory effects as well as promotes the cellular processes of plasticity and memory either by itself through nitrations and nitrosylations or by the synthesis of its second messenger, cGMP, through soluble Guanylyl Cyclase (sGC), which in turn acts through protein kinase $\mathrm{G}$ (PKG) to phosphorylate synaptic proteins. NO

polymorphism confers susceptibility to unipolar depression and treatment response to fluoxetine. No association with disease or SSRI treatment response was found in 108 Chinese can freely cross cellular membranes and act on other cells in a volumedependent manner, e.g., the presynaptic release machinery. Synthesis of $\mathrm{NO}$ can also be stimulated following processes leading to increase in intracellular $\mathrm{Ca}^{2+}$ for example through activation of muscarinic M3 or purinergic P2Y1 receptors. During conditions of stress, the synthesis of nNOS may be altered with consequences on synaptic functioning. For further details, please see main text.

patients (Yu et al. 2003) but due to the restricted design of the study, it is concluded that other variants of the nNOS gene may play a role. Also, in another genetic association analysis 
of case-control samples (325 MDD patients, 154 BP patients and 807 controls) in a Japanese population, using single nucleotide polymorphism (SNP; rs41279104, also called ex1c), no associations between one marker (rs41279104) in nNOS and mood disorder were detected, although the sample sizes were probably too small to allow a meaningful test (Okumura et al. 2010). Moreover, the paper did not perform an association analysis based on linkage disequilibrium and a mutation scan of nNOS (Okumura et al. 2010). In a large genome-wide association study of 435,291 SNPs genotyped in 1738 MDD cases and 1802 controls selected to be at low liability for MDD, it was reported that an association of nNOS with the disease was present, although the size of the NOS-I gene made the authors cautious about the finding (Sullivan et al. 2009). Finally, in a study carried out in a group of 181 depressed patients and 149 control subjects of Polish origin, it was examined whether a single nucleotide polymorphism (SNP) present in the genes encoding iNOS and nNOS could contribute to the risk of developing recurrent depressive disorder (Galecki et al. 2011). It was shown that both investigated polymorphisms could be associated with depression and that the NOS2A and nNOS genes may confer an increased risk of recurrent depressive disorder (Galecki et al. 2011). Recently, a whole-exome sequencing of individuals from an isolated population has identified a significant association in bipolar disorder with NOS1 (missense variant rs79487279) (Lescai et al. 2017). Whether this association could also be relevant for unipolar depressive disorder remains to be established.

Since stressful life events have been considered a crucial environmental triggering factor for depressive episodes (Kendler et al. 2000), a majority of the basic characterization of the involvement of NO in depression has been carried out in animal models involving exposure to stressful situations. Interestingly, nNOS is found expressed in different brain regions related to stress (Arevalo et al. 1992; Bhat et al. 1996; Ceccatelli et al. 1996; Nylén et al. 2001), suggesting NO to be an important modulator of the behavioural and physiological stress response. In addition, the expression of nNOS, along with NO levels, is significantly increased in the brain of animals that have been exposed to stressful stimuli (Harvey et al. 2005; Harvey et al. 2004; Madrigal et al. 2001; Madrigal et al. 2002; Wegener et al. 2010; Zhou et al. 2011). Basal levels of functional iNOS, although in lower levels than nNOS, are also present in the brains of normal healthy adult animals (Amitai 2010), showing significantly higher expression upon stress exposure in different limbic brain regions (Bollinger et al. 2017; Gądek-Michalska et al. 2016; Harvey et al. 2004; Tang et al. 2018). Consistent with the elevated nNOS and/or iNOS expression, increased NO levels can be observed in the hypothalamus, hippocampus and prefrontal cortex of animals exposed to stress in models of depression, such as forced swimming and the chronic mild stress (Gilhotra and Dhingra 2009; Harvey et al. 2005; Harvey et al. 2004; Krass et al.
2010). Simultaneously, neuroendocrine responses to stress, including increased hypothalamus-pituitary adrenal (HPA) axis activity, which is often disrupted in mood disorders (Badenhorst et al. 2017; Brand and Harvey 2017a; Brand and Harvey 2017b; Swaab et al. 2005), can be observed. In fact, a direct relationship between HPA axis activity and NO has been observed, in that endogenously NO inhibits the release of corticotrophin-releasing hormone $(\mathrm{CRH})$, adrenocorticotrophic hormone (ACTH) and corticosterone (Costa et al. 1993; Rivier and Shen 1994a). Studies using systemic injection of different NOS inhibitors suggest that NO may exert a tonic negative influence on the HPA axis activity in the presence or absence of circulating glucocorticoids (Givalois et al. 2002; Rivier and Shen 1994b; Tsuchiya et al. 1997). In contrast, microinjection of an NO donor in the brain ventricles or into brain regions controlling the HPA activity show that NO may increase HPA axis activity (Okada et al. 2002; Seo and Rivier 2001). Such discrepancies can be explained based on the brain region studied, the type and intensity of stimuli triggering HPA axis activation and on the species under investigation (Bugajski et al. 2004; Mancuso et al. 2010; Rivier 2001; Rivier 2003). Nevertheless, there is profound evidence suggesting that NO might be an important messenger in regulating neuroendocrine responses to stress.

Experiments performed with mice with targeted disruption of the nNOS or iNOS genes have suggested a clear involvement of NO on depression neurobiology. Thus, transgenic mice lacking nNOS show hyper locomotor activity in a novel environment, increased social interaction in their home cage and decreased depression-related behaviour, with impaired spatial memory retention (Tanda et al. 2009). Mice lacking nNOS (nNOS-l-) are also more aggressive than wild-type (WT) mice in standard testing paradigms (Nelson et al. 2006). Moreover, nNOS null mutant mice are resistant to stress effects and show a less depressive-like phenotype in the forced swimming and tail suspension tests (Zhou et al. 2007). More importantly, nNOS deletion or intrahippocampal nNOS inhibition blocked the corticosterone-induced behavioural modifications in the chronic mild stress model, thus indicating that hippocampal nNOS is necessary for the role of glucocorticoids in mediating depressive behaviours (Zhou et al. 2011). Since iNOS-mediated NO production is more prominent in response to inflammation and disease, an iNOS -/- phenotype is the increased susceptibility to some infections (Zaragoza et al. 1998; Zaragoza et al. 1999). In addition, the sickness behaviour induced by LPS administration is decreased in iNOS null mice, supporting a prominent role of iNOS in the development of behavioural changes associated to neuroimmunoactivation. However, evidence also supports that iNOS null mice express increased reactivity to stress, in the absence of immunological stimuli, such as increased anxiety in response to predator scent (Abu et al. 2008). On the other hand, iNOS-/- mice also evidenced normal locomotor 
activity and increased resilience in the forced swimming test (Montezuma et al. 2012) and impaired extinction of fear memories (Lisboa et al. 2015). However, with these results, it may be difficult to translate the involvement of iNOS-mediated NO levels to a clinical situation, since the iNOS-deficient animals present compensatory elevated cortical and decreased hippocampal NO levels in response to stress (Abu et al. 2008; Buskila et al. 2007).

In conclusion, both nNOS- and iNOS-derived NO levels are altered in depression and in limbic brain regions of stressed animals. These alterations may contribute to the development of behavioural and endocrine abnormalities that compromise adaptation to stress and increase vulnerability to depression.

\section{No signalling and antidepressant intervention}

The effect of clinically used antidepressants on nitrergic signalling has been shown in a few studies, thus supporting NO involvement in depression and antidepressant action. The first clinical study reported results from a study with patients suffering from ischemic heart disease and depression, 17 received paroxetine and 14 patients nortriptyline and it was observed that serum nitrite and nitrate levels were significantly decreased following paroxetine treatment but not nortriptyline (Finkel et al. 1996). Paroxetine was also shown to be significantly more a potent inhibitor of the NOS enzyme activity than nortriptyline (Finkel et al. 1996). Similarly, several established antidepressants of distinct chemical classes, including imipramine, paroxetine, citalopram and tianeptine, have all been shown to inhibit hippocampal NOS activity in vivo when applied locally in the brain in therapeutically relevant concentrations (Wegener et al. 2003). In another preclinical study, pre-treatment with the main precursor of NO, Larginine, counteracted the antidepressant-like effect of imipramine and venlafaxine but not the effects of bupropion or fluoxetine, effects being associated with decrease in brain NO metabolism (Krass et al. 2011). Similarly, it has been shown Larginine antagonizes the effects of the classic tricyclic antidepressant, imipramine (Harkin et al. 1999). Supporting these findings, a decrease in NMDA stimulated NO synthesis was observed in cultured neurons incubated with antidepressants of different classes ( $\mathrm{Li}$ et al. 2006). However, a more recent study reported that treatment with 7-nitroindazole (7-NI), venlafaxine and fluoxetine attenuated stress-induced neuronal activation in overlapping brain regions, suggesting that nNOS inhibitors and monoaminergic antidepressants may share common neurobiological substrates (Silva et al. 2012). Supporting that hypothesis, it has been demonstrated that low and ineffective doses of L-NAME were able to potentiate the behavioural effects of imipramine and fluoxetine but not reboxetine, a noradrenaline reuptake inhibitor, in the FST (Harkin et al. 2004; Harkin et al. 2003). Altogether, this evidence suggests that attenuation of NO levels might contribute to the behavioural effect of conventional monoaminergic antidepressants.

NO has also been implicated in the antidepressant role of several other substances, like tramadol (Jesse et al. 2008), bupropion (Dhir and Kulkarni 2007) and lithium (Ghasemi et al. 2008). The effects of the fast-acting antidepressant ketamine also seem to involve modulation of NO levels, since Larginine pre-treatment can counteract its effects (Liebenberg et al. 2015; Zhang et al. 2013). More recent evidence suggest that the effects of ketamine could be related to NMDA receptor blockade with subsequent reduced NO-mediated Snitrosylation of a downstream signalling cascade, which disinhibits rapid protein synthesis (Harraz et al. 2016).

In addition to the clinical used antidepressants, specific drugs affecting NO synthesis have been tested for antidepressant efficacy, further corroborating NO involvement in depression neurobiology. A comprehensive review of these compounds lies beyond the scope of this text and can be found elsewhere (Wegener and Volke 2010). Briefly, acute systemic administration of both iNOS and nNOS inhibitors, such as 7NI, 1-(2-trifluoromethylphenyl)-imidazole (TRIM) or 1400W, has antidepressant-like effects but does not affect locomotion (Harkin et al. 2003; Heiberg et al. 2002; Montezuma et al. 2012; Spiacci Jr et al. 2008; Volke et al. 2003; Yildiz et al. 2000). Both 7-NI and TRIM have proven to be effective in other animal models with better face validity, such as the chronic mild stress model of depression (Mutlu et al. 2009; Yazir et al. 2012) and the learned helplessness paradigm (Stanquini et al. 2018). The behavioural effect is centrally based, since inhibition of nNOS into the hippocampus or in the medial prefrontal cortex causes a dose-dependent antidepressant-like effect in the FST (Diniz et al. 2016; Joca and Guimaraes 2006; Pereira et al. 2015; Sales et al. 2017). These findings further support the association of increased stress-induced NO signalling in relevant brain regions with the development of depressive psychopathology.

Interestingly, the importance of intact serotonin signalling has been shown, in that serotonergic depletion abolished the antidepressant-like effect of some NOS inhibitors in the FST (Harkin et al. 2003). This effect seems to have important centrally based neurobiology, since the antidepressant-like effect induced by intrahippocampal administration of a selective nNOS inhibitor could be prevented by co-administering a serotonin $1 \mathrm{~A}$ receptor $\left(5-\mathrm{HT}_{1 \mathrm{a}}\right.$ ) antagonist (Hiroaki-Sato et al. 2014). However, not all inhibitors seem to possess this profile, as it was also demonstrated that the effect of agmatine, which is decarboxylated L-arginine, was independent of the serotonin 5-HT depletion (Krass et al. 2008).

Methylene blue (MB), although not exclusively selective for the NOS, is potentially of special relevance since it is so far 
the only compound proven to be effective in patients (Bodini 1899; Naylor et al. 1986; Naylor et al. 1987; Naylor et al. 1988). Unfortunately, these pioneer studies were not fully randomized but a recent randomized crossover study confirmed efficacy of MB for treatment for residual symptoms of bipolar disorder (Alda et al. 2017). MB does not only inhibit NOS in the brain in vivo (Volke et al. 1999) but also several other haeme-containing enzymes, like monoamine oxidase (MAO) (Ehringer et al. 1961; Gillman 2008; Jakubovic and Necina 1963) and various cytochromes, which may partly account for the clinical efficacy and for the case reports suggesting a hyper serotonergic state following use of MB (Gillman 2008; Stanford et al. 2009). New analogues of MB are being developed (Petzer et al. 2012), which preclinically maintain the antidepressant efficacy without a major effect on MAO (Delport et al. 2017; Delport et al. 2018).

Besides the well-established interaction between NMDA and NO synthesis, alternative pathways, which have also been suggested to be involved in the psychopathology of depression, display convergent mechanisms to NO formation (Fig. 1). Among those, purinergic and muscarinic mechanisms are the most studied. Under stressful conditions, ATP release is increased, leading to the activation of the purinergic $\mathrm{P} 2 \mathrm{X} 7$ receptors (P2X7R), which is highly expressed on neuronal and non-neuronal cells (microglia and astrocytes) (Volonte et al. 2012). Following activation, the $\mathrm{P} 2 \mathrm{X} 7$ receptors allow the influx of $\mathrm{Ca}^{2+}$, formation of the $\mathrm{Ca}-$ calmodulin complex and production of NO (Vorherr et al. 1993). This mechanism seems to be involved in some antidepressant-like effect of P2XR antagonists, since the systemic administration of a P2X antagonist displays antidepressant properties, which were associated with a decrease in the nitrite/nitrate levels in the prefrontal cortex (Pereira et al. 2013). In the same study, a co-localization of nNOS and P2R in the frontal cortex was present and the coupling of these two proteins could be hypothesized to modulate behavioural consequences of stress exposure and the observed antidepressant-like effects following P2XR antagonism (Pereira et al. 2013). Similarly, activation of muscarinic cholinergic receptor (mAchR) subtypes 1,2 and 3 increases the intracellular $\mathrm{Ca}^{2+}$ following their activation by acetylcholine. In fact, studies have shown that stimulation of muscarinic receptors induces NO synthesis and cGMP formation in vitro (Bauer et al. 1994) and in vivo (Fassini et al. 2015). Additionally, it was shown that the activation of $m A$ chR by carbachol has a dose-dependent relationship on nNOS activity, with low doses leading to activation of nNOS, while higher doses inhibited the enzymatic activity (Borda et al. 1998). Surprisingly, it has not yet been investigated if the antidepressant-like effect induced by scopolamine (Dulawa and Janowsky 2018), a muscarinic antagonist, involves modulation of NO levels in the brain.

Finally, since nNOS is anchored to the membrane by the scaffolding protein PSD-95, enabling downstream signalling via the carboxy-terminal PDZ ligand of nNOS (Jaffrey et al. 1998; Jaffrey and Snyder 1996), disruption of this complex specifically prevents NMDA-R signalling coupled to nNOS, while leaving other functions of both the NMDA-R and nNOS intact (Zhou et al. 2010). The antidepressant-like and effects on NO levels of this approach have been demonstrated in a number of studies (Doucet et al. 2013; Doucet et al. 2015), although the results are not always consistent (Tillmann et al. 2017).

\section{No signalling and neuroplasticity in depression}

Neuroplasticity is an important property of neuronal adaptation, which may be disrupted in depression (Manji et al. 2001; Manji et al. 2000). Neuroplasticity changes induced by external environmental factors, such as stress and other negative stimuli, have been demonstrated to play a significant role in both the onset and precipitation of depression (Pittenger and Duman 2008). Conversely, antidepressant intervention has been suggested to exert an important part of the antidepressant effects through regulation of neuroplasticity (Duman and Aghajanian 2012; Duman et al. 2016). It is believed that various neurotrophins, a family of small peptide growth factors, regulate neuroplasticity, which include proliferation, differentiation, survival and death of neuronal cells and supporting tissue (Levy et al. 2018). Brain-derived neurotrophic factor (BDNF), the predominant neurotrophin in the brain, binds to the tropomyosin receptor kinase B (TrkB) receptor and subsequently activates intracellular signalling pathways governing transcription and dendritic translation of proteins necessary for cellular survival, differentiation and learning/ memory formation in the hippocampus (Leal et al. 2017). Importantly, dysfunctional signalling through BDNF and TrkB has been implicated in a number of psychiatric disorders, including depression (Autry and Monteggia 2012). In support of that, stress decreases whereas chronic treatment with antidepressants increases BDNF levels in the prefrontal cortex and in the hippocampus and intact BDNF signalling in the brain is shown to be necessary for the behavioural effects of conventional antidepressants (Adachi et al. 2008; Autry and Monteggia 2012).

Interestingly, $\mathrm{NO}$ seems to be also able to modulate BDNF levels, since it was demonstrated that NO donors (SNP, NOR3) decrease BDNF release in hippocampal cell culture, whereas the inhibition of $\mathrm{NO}$ production increases these levels (Canossa et al. 2002). Accordingly, in vivo experiments showed that chronic treatment with L-NAME increased BDNF mRNA and protein levels in the hippocampus and in the prefrontal cortex of rats (Pinnock and Herbert 2008; Salehpour et al. 2017). In line with this observation, the antidepressant-like effect induced by chronic treatment with 
the selective nNOS inhibitor 7-NI or with the sGC inhibitor ODQ was associated with increased expression of hippocampal BDNF protein levels (Stanquini et al. 2018). Similarly, increased levels of BDNF have also been observed after treatment with other NOS inhibitors, either in cultured or in vivo neocortex (Xiong et al. 1999). However, in another study, the antidepressant effect induced by aminoguanidine, a preferential iNOS inhibitor, was not correlated with increased BDNF signalling in the prefrontal cortex of FSL rats (Silva Pereira et al. 2017). Mice with deficient iNOS expression, however, present increased BDNF levels in the PFC and hippocampus associated to antidepressant-like phenotype (Joca et al. 2012). It is, therefore, likely that both iNOS- and nNOS-derived NO can modulate BDNF signalling in stress adaptation. Although NO has usually been shown to downregulate BDNF levels, peroxynitrite formation derived from $\mathrm{NO}$ and $\mathrm{O}^{2-}$ was observed to trigger TrkB signalling (Yuen et al. 2000), suggesting BDNF signalling to be affected. Evidence from cultured hippocampal neurons indicates that inhibition of BDNF secretions is more pronounced in response to exogenous NO levels or under exacerbated NO concentrations, whereas endogenous low levels of NO would facilitate BDNF-TrkB signalling (Kolarow et al. 2014). A bioinformatic analysis predicted a direct action of $\mathrm{NO}$ on the amino acid residues of BDNF or TrkB, suggesting protein S-nitrosylation or tyrosine nitration in both rodents and humans quoted molecules (Biojone et al. 2015). These direct actions of NO on BDNF or TrkB proteins could trigger functional negative feedback to control protein function, or it could drive a reinforcement of downstream $\mathrm{BDNF} /$ trkB signalling.

Conversely, neurotrophins are also able to modulate $\mathrm{NO}$ or NOS levels, since BDNF has been found to upregulate NO signals, in either hippocampal or neocortical neurons (Kolarow et al. 2014; Xiong et al. 1999). Similarly, the ratio of nNOS-positive neural progenitor cells (NPCs) is increased following treatment with BDNF (Cheng et al. 2003). On the other hand, BDNF can suppress NO production in microglia, thus counteracting inflammatory processes in the brain (Mizoguchi et al. 2014).

More recent evidence indicated that the interplay between $\mathrm{NO}$ and BDNF-TrkB signalling is more complex and involves more signalling cascades. Both NMDA and TrkB can be associated to PSD-95 and induce downstream signalling mechanisms that regulate synaptic plasticity (Cai et al. 2018). In this scenario, PSD-95-nNOS interaction may downregulate BDNF expression via inhibiting ERK activation. On the other hand, NMDA-PSD-95 uncoupling would increase BDNF levels and facilitate BDNF-TrkB-PSD-95 signalling mechanisms related to neuroplasticity, which could contribute to the behavioural effect of these drugs. These results could help explain the effect of NOS inhibitors on BDNF expression.

In humans, a recent study conducted with patients presenting elevated depressive symptoms revealed decreased serum
BDNF levels associated to increase NO levels and impaired antioxidant capacity (Eraldemir et al. 2015). Although it is not possible to infer about brain NO and BDNF levels in these patients, studies conducted with brain tissue from animal's have given further support for a putative role of NO in regulating BDNF levels under stressful situations and depression.

Despite the aforementioned evidence that NO might regulate BDNF levels in stress and depression, evidence about the effects of NOS inhibitors in promoting recovery of impaired synaptogenesis and dendritic branching in stressed animals is scarce. It is known, however, that NO is critically involved in the establishment and activity-dependent refinement of axonal projections during the later stages of development (Manucha 2017). Under physiological concentrations, NO signals downstream, either through sGC activation or through nitrosylation to promote the growth of presynaptic filopodia, which rapidly leads to the formation of new synaptic contacts in in vitro experiments (Sunico et al. 2005). Conversely, high levels of $\mathrm{NO}$, as in nerve injuries, can produce the opposite effect, with reduced synaptogenesis through cGMP-dependent and Snitrosylation-mediated mechanisms (Sunico et al. 2005). Although this can be blocked by treatment with NOS inhibitors (Sunico et al. 2005) and since inhibition of NO synthesis in adult rats increases hippocampal expression of synaptophysin (Joca et al. 2007), it is not known whether blocking NO synthesis may prevent a stress-induced decrease in synaptogenesis and dendritic arboring. However, this seems likely, since PSD-95 promotes synaptogenesis and multiinnervated spine formation through nitric oxide signalling (Nikonenko et al. 2008). However, further research is needed and the question is open for investigation. A proper answer would contribute for a better understanding on the role of NO on stress-induced neuroplasticity related to neuropsychiatric disorders.

Another important neuroplasticy factor affected by NOS inhibitors is neurogenesis, which has been exhaustively reviewed elsewhere (Chong et al. 2018; Gray and Cheung 2014). Only a brief overview is presented here. Neurogenesis is the process of neural stem cells (NSCs) to foster newborn neurons in replacement for damaged neurons or maintaining the function. Neurogenesis has attracted significant interest and although somewhat controversial in humans, it has been suggested that neurogenesis may be linked to recovery from clinical depression (Duman et al. 2001a; Duman et al. 2001b; Spalding et al. 2013) and even in a controversial paper that it may be a prerequisite for an antidepressant response (Santarelli et al. 2003). In the brain, neurogenesis has been observed in the subventricular zone (SVZ) and the subgranular zone of the dentate gyrus (DG) (Ehninger and Kempermann 2008; Spalding et al. 2013). Interestingly, it has also been demonstrated that the subventricular zone is surrounded by nNOS positive neurons (Romero-Grimaldi et al. 2008) and cells expressing nNOS 
have also been identified in neuronal precursors in DG (Islam et al. 2003), suggesting that nNOS could participate in the regulation of neurogenesis. Indeed, it has been demonstrated that the nNOS-mediated suppressing on neurogenesis effect may be caused by NO generated from neurons, not from NSCs (Luo et al. 2010). In addition, evidence that the subcellular localizations of nNOS in neurons and in NSCs seems to be distinct, implying that the role of nNOS in neurons and NSCs is different (Luo et al. 2010). It has also been demonstrated that inhibition of $\mathrm{NO}$ synthesis with 7-NI increases proliferation of neural precursors isolated from the postnatal mouse subventricular zone (Matarredona et al. 2004). However, another report has demonstrated that nNOS inhibition with 7-NI enhanced the proliferation of progenitor cells in the dentate gyrus and that the antidepressant-like effect of this drug was dependent on this neurogenic effect (Zhu et al. 2006). These results are in line with findings using a nNOS knockout mouse line, where the number of new cells, generated in neurogenic areas of the adult brain, the olfactory subependyma and the dentate gyrus, was strongly augmented, indicating that division of neural stem cells in the adult brain can be negatively controlled by NO (Packer et al. 2003). It has also been reported that the nNOS inhibitor L-VNIO or deletion of the nNOS gene could affect the differentiation of NSCs into neurons and astrocytes (Luo et al. 2010). Specifically, it was found that nNOS could facilitate differentiation of hippocampal neural progenitor cells (Park et al. 2017), suggesting that nNOS in NSCs is essential for neurogenesis. In the DG of the hippocampus, NSC forms granule neurons contributing to neuroplasticity, learning and memory. Impairments in these cognitive functions have been observed in nNOS transgenic mice, suggesting that nNOS affects differentiation of NSCs in the DG (Weitzdoerfer et al. 2004). High levels of the nNOS are found in granule neurons in the DG (Islam et al. 2003) and $\mathrm{NO}$ generated from nNOS in these neurons may therefore be speculated to negatively govern granule neuronal precursor proliferation and further reduces differentiation of granule neuronal precursors. Given these observations, it is possible to speculate that the behavioural effects of NOS inhibitors observed in animals under exposure to chronic stress might involve positive regulation of hippocampal neurogenesis.

One of the special physiological properties of NO is the function as a retrograde messenger, influencing synaptic properties, such as LTP and LTD (Izumi and Zorumski 1993; Zorumski and Izumi 1993). Such processes are crucial in synaptic homeostasis and, conversely, affecting NO levels may virtually affect the plasticity and homeostasis of all known synapses (Hardingham et al. 2013; Hölscher 1997). In diseases where synaptic dysfunction, such as depression, is important, $\mathrm{NO}$ is likely to play a major role. In fact, $\mathrm{NO}$ has been shown to mediate local activity-dependent excitatory synapse development and spine dynamics (Nikonenko et al. 2013) and a change in NO levels during development has been shown to promote axon pruning in a cGMP-independent mechanism and to enable a switch between phases of neuronal degeneration and regrowth (Rabinovich et al. 2016).

Changes in synaptic function are similarly reflected in the observed levels of neurotransmitters. Several in vivo studies have demonstrated that $\mathrm{NO}$ can modulate the extracellular level of neurotransmitters in the central nervous system, e.g., 5-HT, DA, GABA and glutamate (Kaehler et al. 1999; Lorrain and Hull 1993; Segovia et al. 1997; Segovia et al. 1999; Segovia et al. 1994; Strasser et al. 1994; Wegener et al. 2000). In addition, NO can inactivate the rate limiting enzyme in the synthesis of 5-HT, tryptophan hydroxylase (Kuhn and Arthur Jr. 1996, 1997) and it has been suggested to stimulate synaptic vesicle release from hippocampal synaptosomes (Meffert et al. 1996; Meffert et al. 1994). Furthermore, NO regulates 5-HT reuptake (Pogun et al. 1994a; Pogun et al. 1994b; Pogun and Kuhar 1994), inhibits uptake of [3H] DA by striatal synaptosomes (Lonart et al. 1993; Lonart and Johnson 1994) and transforms 5-HT into an inactive form (Fossier et al. 1999). It has also been demonstrated that a physical interaction between the serotonin transporter and neuronal nitric oxide synthase, via PDZ-PDZ interactions, may underlie reciprocal modulation of their activity (Chanrion et al. 2007). The connection between NO and 5HT is substantiated by observations showing that NO as well as 5-HT are involved in the pathophysiology of migraine (Lassen et al. 1998; Lassen et al. 1997; Thomsen 1997; Thomsen and Olesen 1998), as well as the inverse relationship between NO and 5-HT in peripheral tissue. These neurochemical studies could provide evidence for the observation that the antidepressant-like effect induced by NOS inhibitors is dependent on brain serotonin levels.

\section{Conclusion and perspectives}

Evidence from preclinical models has consistently shown that inhibiting NO synthesis can lead to antidepressant-like effects. These effects can be achieved through different pharmacological mechanisms, including direct nNOS and/or iNOS inhibition, blockade of $\mathrm{P} 2$ receptors or muscarinic receptors. As a result, reduced NO levels could allow appropriate monoaminergic signalling during stress to promote behavioural adaptation. In this scenario, it is likely that upon chronic exposure to stress, continuous inhibition of NO synthesis could facilitate neuroplastic mechanisms related to the antidepressant effect, such as increased BDNF-TrkB signalling and neurogenesis.

Despite significant advances in this field, challenges remain in developing compounds that may differentially inhibit the 'right' NOS isoform at the right place. However, the NO system continues to be an interesting approach in the future development of antidepressants. 
Funding information The authors wish to acknowledge CNPq (grant 306648/2014-8 to SJ), the AIAS-Cofund (Marie Curie) Fellowship Program (SJ), FAPESP (research fellowship to CAFD), CNPq (post-doctoral fellowship (AGS) and $\mathrm{PhD}$ fellowships (ALR), Independent Research Fund Denmark (grant 8020-00310B to GW), Aarhus University Research Foundation (AU-IDEAS initiative (eMOOD) to GW) and EU Horizon 2020 (ExEDE to GW).

\section{Compliance with ethical standards}

Conflict of interest GW declares having received research support/lecture/consultancy fees from $\mathrm{H}$. Lundbeck A/S, Servier SA, Astra Zeneca AB, Eli Lilly A/S, Sun Pharma Pty Ltd., Pfizer Inc., Shire A/S, HB Pharma A/S, Arla Foods A.m.b.A., Alkermes Inc., Johnson \& Johnson Inc. and Mundipharma International Ltd. All other authors declare no conflict of interest.

Open Access This article is distributed under the terms of the Creative Commons Attribution 4.0 International License (http:// creativecommons.org/licenses/by/4.0/), which permits unrestricted use, distribution and reproduction in any medium, provided you give appropriate credit to the original author(s) and the source, provide a link to the Creative Commons license and indicate if changes were made.

Publisher's Note Springer Nature remains neutral with regard to jurisdictional claims in published maps and institutional affiliations.

\section{References}

Abu-Ghanem Y, Cohen H, Buskila Y, Grauer E, Amitai Y (2008) Enhanced stress reactivity in nitric oxide synthase type 2 mutant mice: findings in support of astrocytic nitrosative modulation of behavior. Neurosci 156:257-265

Adachi M, Barrot M, Autry AE, Theobald D, Monteggia LM (2008) Selective loss of brain-derived neurotrophic factor in the dentate gyrus attenuates antidepressant efficacy. Biol Psychiatry 63:642649

Alda M, McKinnon M, Blagdon R, Garnham J, MacLellan S, O’Donovan C, Hajek T, Nair C, Dursun S, MacQueen G (2017) Methylene blue treatment for residual symptoms of bipolar disorder: randomised crossover study. Br J Psychiatry 210:54-60

Amitai Y (2010) Physiologic role for "inducible" nitric oxide synthase: a new form of astrocytic-neuronal interface. Glia 58:1775-1781

Arevalo R, Sanchez F, Alonso JR, Carretero J, Vazquez R, Aijon J (1992) NADPH-diaphorase activity in the hypothalamic magnocellular neurosecretory nuclei of the rat. Brain Res Bull 28:599-603

Autry AE, Monteggia LM (2012) Brain-derived neurotrophic factor and neuropsychiatric disorders. Pharmacol Rev 64:238-258

Badenhorst NJ, Brand L, Harvey BH, Ellis SM, Brink CB (2017) Longterm effects of pre-pubertal fluoxetine on behaviour and monoaminergic stress response in stress-sensitive rats. Acta Neuropsychiatr 29:222-235

Bauer MB, Murphy S, Gebhart GF (1994) Muscarinic cholinergic stimulation of the nitric oxide-cyclic GMP signaling system in cultured rat sensory neurons. Neurosci 62:351-359

Bernstein HG, Stanarius A, Baumann B, Henning H, Krell D, Danos P, Falkai P, Bogerts B (1998) Nitric oxide synthase-containing neurons in the human hypothalamus: reduced number of immunoreactive cells in the paraventricular nucleus of depressive patients and schizophrenics. Neurosci 83:867-875

Bernstein HG, Heinemann A, Krell D, Mawrin C, Bielau H, Danos P, Diekmann S, Keilhoff G, Bogerts B, Baumann B (2002) Further immunohistochemical evidence for impaired NO signaling in the hypothalamus of depressed patients. Ann N Y Acad Sci 973:91-93

Bhat G, Mahesh VB, Aguan K, Brann DW (1996) Evidence that brain nitric oxide synthase is the major nitric oxide synthase isoform in the hypothalamus of the adult female rat and that nitric oxide potently regulates hypothalamic cGMP levels. Neuroendocrinology 64:93102

Biojone C, Casarotto PC, Joca SR, Castren E (2015) Interplay between nitric oxide and brain-derived neurotrophic factor in neuronal plasticity. CNS Neurol Disord Drug Targets 14:979-987

Bodini $\mathrm{P}$ (1899) Le bleu de méthylène comme calmant chez le aliénés. La Semaine Médicale 56

Bollinger JL, Collins KE, Patel R, Wellman CL (2017) Behavioral stress alters corticolimbic microglia in a sex- and brain region-specific manner. PLoS One 12:e0187631

Borda T, Genaro A, Sterin-Borda L, Cremaschi G (1998) Involvement of endogenous nitric oxide signalling system in brain muscarinic acetylcholine receptor activation. J Neural Transm (Vienna) 105:193204

Brand SJ, Harvey BH (2017a) Exploring a post-traumatic stress disorder paradigm in Flinders sensitive line rats to model treatment-resistant depression I: bio-behavioural validation and response to imipramine. Acta Neuropsychiatr 29:193-206

Brand SJ, Harvey BH (2017b) Exploring a post-traumatic stress disorder paradigm in Flinders sensitive line rats to model treatment-resistant depression II: response to antidepressant augmentation strategies. Acta Neuropsychiatr 29:207-221

Bugajski J, Gadek-Michalska A, Bugajski AJ (2004) Nitric oxide and prostaglandin systems in the stimulation of hypothalamic-pituitaryadrenal axis by neurotransmitters and neurohormones. J Physiol Pharmacol 55:679-703

Buskila Y, Abu-Ghanem Y, Levi Y, Moran A, Grauer E, Amitai Y (2007) Enhanced astrocytic nitric oxide production and neuronal modifications in the neocortex of a NOS2 mutant mouse. PLoS One 2:e843

Cai C-Y, Chen C, Zhou Y, Han Z, Qin C, Cao B, Tao Y, Bian X-L, Lin YH, Chang L, Wu H-Y, Luo C-X, Zhu D-Y (2018) PSD-95-nNOS coupling regulates contextual fear extinction in the Dorsal CA3. Sci Rep 8:12775

Canossa M, Giordano E, Cappello S, Guarnieri C, Ferri S (2002) Nitric oxide down-regulates brain-derived neurotrophic factor secretion in cultured hippocampal neurons. Proc Natl Acad Sci U S A 99:32823287

Caspi A, Sugden K, Moffitt TE, Taylor A, Craig IW, Harrington H, McClay J, Mill J, Martin J, Braithwaite A, Poulton R (2003) Influence of life stress on depression: moderation by a polymorphism in the 5-HTT gene. Science 301:386-389

Ceccatelli S, Grandison L, Scott REM, Pfaff DW, Kow LM (1996) Estradiol regulation of nitric oxide synthase mRNAs in rat hypothalamus. Neuroendocrinology 64:357-363

Chang C-K, Hayes RD, Perera G, Broadbent MTM, Fernandes AC, Lee WE, Hotopf M, Stewart R (2011) Life expectancy at birth for people with serious mental illness and other major disorders from a secondary mental health care case register in London. PLoS One 6:e19590

Chanrion B, Mannoury la Cour C, Bertaso F, Lerner-Natoli M, Freissmuth M, Millan MJ, Bockaert J, Marin P (2007) Physical interaction between the serotonin transporter and neuronal nitric oxide synthase underlies reciprocal modulation of their activity. Proc Natl Acad Sci U S A 104:8119-8124

Cheng A, Wang S, Cai J, Rao MS, Mattson MP (2003) Nitric oxide acts in a positive feedback loop with BDNF to regulate neural progenitor cell proliferation and differentiation in the mammalian brain. DevBiol 258:319-333

Chisholm D, Sweeny K, Sheehan P, Rasmussen B, Smit F, Cuijpers P, Saxena S (2016) Scaling-up treatment of depression and anxiety: a global return on investment analysis. Lancet Psychiatry 3:415-424 
Chong CM, Ai N, Ke M, Tan Y, Huang Z, Li Y, Lu JH, Ge W, Su H (2018) Roles of nitric oxide synthase isoforms in neurogenesis. Mol Neurobiol 55:2645-2652

Cipriani A, Furukawa TA, Salanti G, Chaimani A, Atkinson LZ, Ogawa Y, Leucht S, Ruhe HG, Turner EH, Higgins JPT, Egger M, Takeshima N, Hayasaka Y, Imai H, Shinohara K, Tajika A, Ioannidis JPA, Geddes JR (2018) Comparative efficacy and acceptability of 21 antidepressant drugs for the acute treatment of adults with major depressive disorder: a systematic review and network meta-analysis. Lancet 391:1357-1366

Costa A, Trainer P, Besser M, Grossman A (1993) Nitric oxide modulates the release of corticotropin-releasing hormone from the rat hypothalamus in vitro. Brain Res 605:187-192

Delport A, Harvey BH, Petzer A, Petzer JP (2017) Methylene blue and its analogues as antidepressant compounds. Metab Brain Dis 32:13571382

Delport A, Harvey BH, Petzer A, Petzer JP (2018) Methylene blue analogues with marginal monoamine oxidase inhibition retain antidepressant-like activity. ACS Chem Neurosci

Dhir A, Kulkarni SK (2007) Involvement of nitric oxide (NO) signaling pathway in the antidepressant action of bupropion, a dopamine reuptake inhibitor. Eur J Pharmacol 568:177-185

Ding JD, Burette A, Nedvetsky PI, Schmidt HH, Weinberg RJ (2004) Distribution of soluble guanylyl cyclase in the rat brain. J Comp Neurol 472:437-448

Diniz CR, Casarotto PC, Joca SR (2016) NMDA-NO signaling in the dorsal and ventral hippocampus time-dependently modulates the behavioral responses to forced swimming stress. Behav Brain Res 307:126-136

Doucet MV, Levine H, Dev KK, Harkin A (2013) Small-molecule inhibitors at the PSD-95/nNOS interface have antidepressant-like properties in mice. Neuropsychopharmacol 38:1575-1584

Doucet MV, O'Toole E, Connor T, Harkin A (2015) Small-molecule inhibitors at the PSD-95/nNOS interface protect against glutamateinduced neuronal atrophy in primary cortical neurons. Neurosci 301: $421-438$

Dulawa SC, Janowsky DS (2018) Cholinergic regulation of mood: from basic and clinical studies to emerging therapeutics. Mol Psychiatry

Duman RS, Aghajanian GK (2012) Synaptic dysfunction in depression: potential therapeutic targets. Science 338:68-72

Duman RS, Malberg J, Nakagawa S (2001a) Regulation of adult neurogenesis by psychotropic drugs and stress. J Pharmacol Exp Ther 299:401-407

Duman RS, Nakagawa S, Malberg J (2001b) Regulation of adult neurogenesis by antidepressant treatment. Neuropsychopharmacol $25: 836-844$

Duman RS, Aghajanian GK, Sanacora G, Krystal JH (2016) Synaptic plasticity and depression: new insights from stress and rapid-acting antidepressants. Nat Med 22:238

Ehninger D, Kempermann G (2008) Neurogenesis in the adult hippocampus. Cell Tissue Res 331:243-250

Ehringer H, Hornykiewicz O, Lechner K (1961) Die Wirkung von Methylenblau auf die Monoaminoxydase und den Katecholaminund 5-Hydroxytryptaminstoffwechsel des Gehirnes. Naunyn Schmiedebergs Arch Exp Pathol Pharmakol 241:568-582

Eraldemir FC, Ozsoy D, Bek S, Kir H, Dervisoglu E (2015) The relationship between brain-derived neurotrophic factor levels, oxidative and nitrosative stress and depressive symptoms: a study on peritoneal dialysis. Ren Fail 37:722-726

Fassini A, Antero LS, Corrêa FMA, Joca SR, Resstel LBM (2015) The prelimbic cortex muscarinic M3 receptor-nitric oxide-guanylyl cyclase pathway modulates cardiovascular responses in rats. 93:830838

Feil R, Kleppisch T (2008) NO/cGMP-dependent modulation of synaptic transmission. Handb Exp Pharmacol:529-560
Finkel MS, Laghrissi-Thode F, Pollock BG, Rong J (1996) Paroxetine is a novel nitric oxide synthase inhibitor. Psychopharmacol Bull 32: 653-658

Florenzano F, Viscomi MT, Amadio S, D'Ambrosi N, Volonte C, Molinari M (2008) Do ATP and NO interact in the CNS? Prog Neurobiol 84:40-56

Fossier P, Blanchard B, Ducrocq C, Leprince C, Tauc L, Baux G (1999) Nitric oxide transforms serotonin into an inactive form and this affects neuromodulation. Neurosci 93:597-603

Gądek-Michalska A, Tadeusz J, Rachwalska P, Bugajski J (2016) Psychosocial stress inhibits additional stress-induced hyperexpression of NO synthases and IL-1 $\beta$ in brain structures. Pharmacol Rep 68:1178-1196

Galecki P, Maes M, Florkowski A, Lewinski A, Galecka E, Bienkiewicz M, Szemraj J (2011) Association between inducible and neuronal nitric oxide synthase polymorphisms and recurrent depressive disorder. J Affect Disord 129:175-182

Garthwaite J (2008) Concepts of neural nitric oxide-mediated transmission. Eur J Neurosci 27:2783-2802

Garthwaite J, Charles SL, Chess-Williams R (1988) Endothelium-derived relaxing factor release on activation of NMDA receptors suggests role as intercellular messenger in the brain. Nature 336:385-388

Ghasemi M, Sadeghipour H, Mosleh A, Sadeghipour HR, Mani AR, Dehpour AR (2008) Nitric oxide involvement in the antidepressant-like effects of acute lithium administration in the mouse forced swimming test. Eur Neuropsychopharmacol 18:323332

Gilhotra N, Dhingra D (2009) Involvement of NO-cGMP pathway in anti-anxiety effect of aminoguanidine in stressed mice. Prog Neuro-Psychopharmacol Biol Psychiatry 33:1502-1507

Gillman PK (2008) Methylene blue is a potent monoamine oxidase inhibitor. Can J Anaesth 55:311-312 author reply 312

Givalois L, Li S, Pelletier G (2002) Central nitric oxide regulation of the hypothalamic-pituitary-adrenocortical axis in adult male rats. Mol Brain Res 102:1-8

Gray WP, Cheung A (2014) Chapter four-nitric oxide regulation of adult neurogenesis. In: Litwack G (ed) Vitamins \& hormones, vol 96. Academic Press, pp 59-77

Guix FX, Uribesalgo I, Coma M, Munoz FJ (2005) The physiology and pathophysiology of nitric oxide in the brain. Prog Neurobiol 76: $126-152$

Hardingham N, Dachtler J, Fox K (2013) The role of nitric oxide in presynaptic plasticity and homeostasis. Front Cell Neurosci 7:190

Harkin AJ, Bruce KH, Craft B, Paul IA (1999) Nitric oxide synthase inhibitors have antidepressant-like properties in mice. 1. Acute treatments are active in the forced swim test. Eur J Pharmacol 372:207213

Harkin A, Connor TJ, Walsh M, St John N, Kelly JP (2003) Serotonergic mediation of the antidepressant-like effects of nitric oxide synthase inhibitors. Neuropharmacol 44:616-623

Harkin A, Connor TJ, Burns MP, Kelly JP (2004) Nitric oxide synthase inhibitors augment the effects of serotonin re-uptake inhibitors in the forced swimming test. Eur Neuropsychopharmacol 14:274-281

Harraz MM, Tyagi R, Cortes P, Snyder SH (2016) Antidepressant action of ketamine via mTOR is mediated by inhibition of nitrergic Rheb degradation. Mol Psychiatry 21:313-319

Harvey BH, Oosthuizen F, Brand L, Wegener G, Stein DJ (2004) Stressrestress evokes sustained iNOS activity and altered GABA levels and NMDA receptors in rat hippocampus. Psychopharmacol (Berl) 175:494-502

Harvey BH, Bothma T, Nel A, Wegener G, Stein DJ (2005) Involvement of the NMDA receptor, NO-cyclic GMP and nuclear factor K-beta in an animal model of repeated trauma. Hum Psychopharmacol 20: $367-373$ 
Hasin DS, Sarvet AL, Meyers JL et al (2018) Epidemiology of adult dsm5 major depressive disorder and its specifiers in the United States. JAMA Psychiatry 75:336-346

Heiberg IL, Wegener G, Rosenberg R (2002) Reduction of cGMP and nitric oxide has antidepressant-like effects in the forced swimming test in rats. Behav Brain Res 134:479-484

Herken H, Gurel A, Selek S, Armutcu F, Ozen ME, Bulut M, Kap O, Yumru M, Savas HA, Akyol O (2007) Adenosine deaminase, nitric oxide, superoxide dismutase, and xanthine oxidase in patients with major depression: impact of antidepressant treatment. Arch Med Res 38:247-252

Hiroaki-Sato VA, Sales AJ, Biojone C, Joca SR (2014) Hippocampal nNOS inhibition induces an antidepressant-like effect: involvement of 5HT1A receptors. Behav Pharmacol 25:187-196

Hölscher C (1997) Nitric oxide, the enigmatic neuronal messenger: its role in synaptic plasticity. Trends Neurosci 20:298-303

Islam ATMS, Kuraoka A, Kawabuchi M JASI(2003) Morphological basis of nitric oxide production and its correlation with the polysialylated precursor cells in the dentate gyrus of the adult guinea pig hippocampus. Anat Sci Int 78:98-103

Izumi Y, Zorumski CF (1993) Nitric oxide and long-term synaptic depression in the rat hippocampus. Neuroreport 4:1131-1134

Jaffrey SR, Snyder SH (1996) PIN: an associated protein inhibitor of neuronal nitric oxide synthase. Science 274:774-777

Jaffrey SR, Snowman AM, Eliasson MJ, Cohen NA, Snyder SH (1998) CAPON: a protein associated with neuronal nitric oxide synthase that regulates its interactions with PSD95. Neuron 20:115-124

Jaffrey SR, Erdjument-Bromage H, Ferris CD, Tempst P, Snyder SH (2001) Protein S-nitrosylation: a physiological signal for neuronal nitric oxide. Nat Cell Biol 3:193-197

Jakubovic A, Necina J (1963) The effect of methylene blue on the monoamine oxidase activity of the liver and brain of rats after various routes of administration. Arzneimittelforschung 13:134-136

Jesse CR, Bortolatto CF, Savegnago L, Rocha JB, Nogueira CW (2008) Involvement of L-arginine-nitric oxide-cyclic guanosine monophosphate pathway in the antidepressant-like effect of tramadol in the rat forced swimming test. Prog Neuro-Psychopharmacol Biol Psychiatry 32:1838-1843

Joca SR, Guimaraes FS (2006) Inhibition of neuronal nitric oxide synthase in the rat hippocampus induces antidepressant-like effects. Psychopharmacol (Berl) 185:298-305

Joca SR, Guimaraes FS, Del-Bel E (2007) Inhibition of nitric oxide synthase increases synaptophysin mRNA expression in the hippocampal formation of rats. Neurosci Lett 421:72-76

Joca S, Biojone C, Casarotto P, Montezuma K, Cunha F, Guimaraes F (2012) BDNF-TrkB signaling is involved in the antidepressant-like effect induced by genetic deletion of iNOS. Int $J$ Neuropsychopharmacol 15:44-45

Kaehler ST, Singewald N, Sinner C, Philippu A (1999) Nitric oxide modulates the release of serotonin in the rat hypothalamus. Brain Res 835:346-349

Karolewicz B, Szebeni K, Stockmeier CA, Konick L, Overholser JC, Jurjus G, Roth BL, Ordway GA (2004) Low nNOS protein in the locus coeruleus in major depression. J Neurochem 91:1057-1066

Kendler KS, Thornton LM, Gardner CO (2000) Stressful life events and previous episodes in the etiology of major depression in women: an evaluation of the 'kindling' hypothesis. AJ Psychiatry 157:12431251

Kessler RC, Bromet EJ (2013) The epidemiology of depression across cultures. Annu Rev Public Health 34:119-138

Kim YK, Paik JW, Lee SW, Yoon D, Han C, Lee BH (2006) Increased plasma nitric oxide level associated with suicide attempt in depressive patients. Prog Neuro-Psychopharmacol Biol Psychiatry 30: 1091-1096

Kleppisch T, Feil R (2009) cGMP Signalling in the mammalian brain: role in synaptic plasticity and behaviour. In: Schmidt HHHW,
Hofmann F, Stasch JP (eds) cGMP: generators, effectors and therapeutic implications. Handbook of Experimental Pharmacology, 191: 549-79. Springer, Berlin, Heidelberg

Kolarow R, Kuhlmann CR, Munsch T, Zehendner C, Brigadski T, Luhmann HJ, Lessmann V (2014) BDNF-induced nitric oxide signals in cultured rat hippocampal neurons: time course, mechanism of generation, and effect on neurotrophin secretion. Front Cell Neurosci 8:323

Krass M, Wegener G, Vasar E, Volke V (2008) Antidepressant-like effect of agmatine is not mediated by serotonin. Behav Brain Res 188: 324-328

Krass M, Runkorg K, Wegener G, Volke V (2010) Nitric oxide is involved in the regulation of marble-burying behavior. Neurosci Lett 480:55-58

Krass M, Wegener G, Vasar E, Volke V (2011) The antidepressant action of imipramine and venlafaxine involves suppression of nitric oxide synthesis. Behav Brain Res 218:57-63

Kuhn DM, Arthur RE Jr (1996) Inactivation of brain tryptophan hydroxylase by nitric oxide. J Neurochem 67:1072-1077

Kuhn DM, Arthur R Jr (1997) Molecular mechanism of the inactivation of tryptophan hydroxylase by nitric oxide: attack on critical sulfhydryls that spare the enzyme iron center. J Neurosci 17:7245-7251

Lassen LH, Ashina M, Christiansen I, Ulrich V, Olesen J (1997) Nitric oxide synthase inhibition in migraine [letter]. Lancet 349:401-402

Lassen LH, Ashina M, Christiansen I, Ulrich V, Grover R, Donaldson J, Olesen J (1998) Nitric oxide synthase inhibition: a new principle in the treatment of migraine attacks. Cephalalgia 18:27-32

Lasserre AM, Marti-Soler H, Strippoli M-PF, Vaucher J, Glaus J, Vandeleur CL, Castelao E, Marques-Vidal P, Waeber G, Vollenweider P, Preisig M (2016) Clinical and course characteristics of depression and all-cause mortality: a prospective populationbased study. J Affect Disord 189:17-24

Laursen TM, Musliner KL, Benros ME, Vestergaard M, Munk-Olsen T (2016) Mortality and life expectancy in persons with severe unipolar depression. J Affect Disord 193:203-207

Leal G, Bramham CR, Duarte CB (2017) Chapter eight-BDNF and hippocampal synaptic plasticity. In: Litwack G (ed) Vitamins and hormones, vol 104. Academic Press, pp 153-195

Lee BH, Lee SW, Yoon D, Lee HJ, Yang JC, Shim SH, Kim DH, Ryu SH, Han C, Kim YK (2006) Increased plasma nitric oxide metabolites in suicide attempters. Neuropsychobiology 53:127-132

Lescai F, Als TD, Li Q, Nyegaard M, Andorsdottir G, Biskopstø M, Hedemand A, Fiorentino A, O'Brien N, Jarram A, Liang J, Grove J, Pallesen J, Eickhardt E, Mattheisen M, Bolund L, Demontis D, Wang AG, McQuillin A, Mors O, Wang J, Børglum AD (2017) Whole-exome sequencing of individuals from an isolated population implicates rare risk variants in bipolar disorder. Transl Psychiatry 7:e1034

Levy MJF, Boulle F, Steinbusch HW, van den Hove DLA, Kenis G, Lanfumey LJP (2018) Neurotrophic factors and neuroplasticity pathways in the pathophysiology and treatment of depression. Psychopharmacology (Berl) 235:2195-2220

Li Y-F, Zhang Y-Z, Liu Y-Q, Wang H-L, Cao J-B, Guan T-T, Luo Z-P (2006) Inhibition of N-methyl-D-aspartate receptor function appears to be one of the common actions for antidepressants. J Psychopharmacol 20:629-635

Liebenberg N, Joca S, Wegener G (2015) Nitric oxide involvement in the antidepressant-like effect of ketamine in the Flinders sensitive line rat model of depression. Acta Neuropsychiatr 27:90-96

Lisboa SF, Gomes FV, Silva AL, Uliana DL, Camargo LH, Guimaraes FS, Cunha FQ, Joca SR, Resstel LB (2015) Increased contextual fear conditioning in iNOS knockout mice: additional evidence for the involvement of nitric oxide in stress-related disorders and contribution of the endocannabinoid system. Int J Neuropsychopharmacol 18(8):pyv005. https://doi.org/10.1093/ ijnp/pyv005 
Lonart G, Johnson KM (1994) Inhibitory effects of nitric oxide on the uptake of $[3 \mathrm{H}]$ dopamine and $[3 \mathrm{H}]$ glutamate by striatal synaptosomes. J Neurochem 63:2108-2117

Lonart G, Cassels KL, Johnson KM (1993) Nitric oxide induces calciumdependent $[3 \mathrm{H}]$ dopamine release from striatal slices. J NeurosciRes 35:192-198

Lorrain DS, Hull EM (1993) Nitric oxide increases dopamine and serotonin release in the medial preoptic area. Neuroreport 5:87-89

Luo C-X, Jin X, Cao C-C, Zhu M-M, Wang B, Chang L, Zhou Q-G, Wu H-Y, Zhu D-Y (2010) BIdirectional regulation of neurogenesis by neuronal nitric oxide synthase derived from neurons and neural stem cells. 28:2041-2052

Madrigal JL, Moro MA, Lizasoain I, Lorenzo P, Castrillo A, Bosca L, Leza JC (2001) Inducible nitric oxide synthase expression in brain cortex after acute restraint stress is regulated by nuclear factor kappaB-mediated mechanisms. J Neurochem 76:532-538

Madrigal JLM, Moro MA, Lizasoain I, Lorenzo P, Leza JC (2002) Stressinduced increase in extracellular sucrose space in rats is mediated by nitric oxide. Brain Res 938:87-91

Mancuso C, Navarra P, Preziosi P (2010) Roles of nitric oxide, carbon monoxide, and hydrogen sulfide in the regulation of the hypothalamic-pituitary-adrenal axis. J Neurochem 113:563-575

Manji HK, Moore GJ, Rajkowska G, Chen G (2000) Neuroplasticity and cellular resilience in mood disorders. Mol Psychiatry 5:578-593

Manji HK, Drevets WC, Charney DS (2001) The cellular neurobiology of depression. NatMed 7:541-547

Manucha W (2017) Mitochondrial dysfunction associated with nitric oxide pathways in glutamate neurotoxicity. Clínica e Investigación en Arteriosclerosis 29:92-97

Marcoli M, Maura G, Tortarolo M, Raiteri M (1997) Serotonin inhibition of the NMDA receptor/nitric oxide/cyclic GMP pathway in rat cerebellum: involvement of 5-hydroxytryptamine $2 \mathrm{C}$ receptors. $\mathrm{J}$ Neurochem 69:427-430

Matarredona ER, Murillo-Carretero M, Moreno-López B, Estrada C (2004) Nitric oxide synthesis inhibition increases proliferation of neural precursors isolated from the postnatal mouse subventricular zone. Brain Res 995:274-284

Meffert MK, Premack BA, Schulman H (1994) Nitric oxide stimulates $\mathrm{Ca}(2+)$-independent synaptic vesicle release. Neuron 12:1235-1244

Meffert MK, Calakos NC, Scheller RH, Schulman H (1996) Nitric oxide modulates synaptic vesicle docking fusion reactions. Neuron 16: 1229-1236

Mizoguchi Y, Kato TA, Seki Y, Ohgidani M, Sagata N, Horikawa H, Yamauchi Y, Sato-Kasai M, Hayakawa K, Inoue R, Kanba S, Monji A (2014) Brain-derived neurotrophic factor (BDNF) induces sustained intracellular $\mathrm{Ca} 2+$ elevation through the up-regulation of surface transient receptor potential 3 (TRPC3) channels in rodent microglia. J Biol Chem 289:18549-18555

Montezuma K, Biojone C, Lisboa SF, Cunha FQ, Guimaraes FS, Joca SR (2012) Inhibition of iNOS induces antidepressant-like effects in mice: pharmacological and genetic evidence. Neuropharmacol 62: 485-491

Mutlu O, Ulak G, Laugeray A, Belzung C (2009) Effects of neuronal and inducible NOS inhibitor 1-[2-(trifluoromethyl) phenyl] imidazole (TRIM) in unpredictable chronic mild stress procedure in mice. Pharmacol Biochem Behav 92:82-87

Naylor GJ, Martin B, Hopwood SE, Watson Y (1986) A two-year doubleblind crossover trial of the prophylactic effect of methylene blue in manic-depressive psychosis. Biol Psychiatry 21:915-920

Naylor GJ, Smith AH, Connelly P (1987) A controlled trial of methylene blue in severe depressive illness. Biol Psychiatry 22:657-659

Naylor GJ, Smith AH, Connelly P (1988) Methylene blue in mania [letter]. Biol Psychiatry 24:941-942

Nelson RJ, Trainor BC, Chiavegatto S, Demas GE (2006) Pleiotropic contributions of nitric oxide to aggressive behavior. Neurosci Biobehav Rev 30:346-355
Nikonenko I, Boda B, Steen S, Knott G, Welker E, Muller D (2008) PSD95 promotes synaptogenesis and multiinnervated spine formation through nitric oxide signaling. 183:1115-1127

Nikonenko I, Nikonenko A, Mendez P, Michurina TV, Enikolopov G, Muller D (2013) Nitric oxide mediates local activity-dependent excitatory synapse development. 110:E4142-E4151

Nylén A, Skagerberg G, Alm P, Larsson B, Holmqvist B, Andersson KE (2001) Nitric oxide synthase in the hypothalamic paraventricular nucleus of the female rat; organization of spinal projections and coexistence with oxytocin or vasopressin. Brain Res 908:10-24

Okada S, Murakami Y, Yokotani K (2002) Centrally applied nitric oxide donor elevates plasma corticosterone by activation of the hypothalamic noradrenergic neurons in rats. Brain Res 939:26-33

Okumura T, Kishi T, Okochi T, Ikeda M, Kitajima T, Yamanouchi Y, Kinoshita Y, Kawashima K, Tsunoka T, Inada T, Ozaki N, Iwata N (2010) Genetic association analysis of functional polymorphisms in neuronal nitric oxide synthase 1 gene (NOS1) and mood disorders and fluvoxamine response in major depressive disorder in the Japanese population. Neuropsychobiology 61:57-63

Olesen J, Leonardi M (2003) The burden of brain diseases in Europe. Eur J Neurol 10:471-477

Olesen J, Sobscki P, Truelsen T, Sestoft D, Jonsson B (2008) Cost of disorders of the brain in Denmark. NordJ Psychiatry 62:114-120

Oliveira RM, Guimaraes FS, Deakin JF (2008) Expression of neuronal nitric oxide synthase in the hippocampal formation in affective disorders. Braz J Med Biol Res 41:333-341

Packer MA, Stasiv Y, Benraiss A, Chmielnicki E, Grinberg A, Westphal H, Goldman SA, Enikolopov G (2003) Nitric oxide negatively regulates mammalian adult neurogenesis. Proc Natl Acad Sci U S A 100:9566-9571

Park S-Y, Kang M-J, Han J-SJMN (2017) Neuronal NOS induces neuronal differentiation through a PKC $\alpha$-dependent GSK $3 \beta$ inactivation pathway in hippocampal neural progenitor cells. Mol Neurobiol 54: 5646-5656

Pereira VS, Casarotto PC, Hiroaki-Sato VA, Sartim AG, Guimaraes FS, Joca SR (2013) Antidepressant- and anticompulsive-like effects of purinergic receptor blockade: involvement of nitric oxide. Eur Neuropsychopharmacol 23:1769-1778

Pereira VS, Romano A, Wegener G, Joca SR (2015) Antidepressant-like effects induced by NMDA receptor blockade and NO synthesis inhibition in the ventral medial prefrontal cortex of rats exposed to the forced swim test. Psychopharmacol (Berl) 232(13):2263-2273

Petzer A, Harvey BH, Wegener G, Petzer JP (2012) Azure B, a metabolite of methylene blue, is a high-potency, reversible inhibitor of monoamine oxidase. Toxicol Appl Pharmacol 258:403-409

Pinnock SB, Herbert J (2008) Brain-derived neurotropic factor and neurogenesis in the adult rat dentate gyrus: interactions with corticosterone. Eur J Neurosci 27:2493-2500

Pittenger C, Duman RS (2008) Stress, depression, and neuroplasticity: a convergence of mechanisms. Neuropsychopharmacol 33:88-109

Pogun S, Kuhar MJ (1994) Regulation of neurotransmitter reuptake by nitric oxide. Ann N Y Acad Sci 738(305-15):305-315

Pogun S, Baumann MH, Kuhar MJ (1994a) Nitric oxide inhibits [3H]dopamine uptake. Brain Res 641:83-91

Pogun S, Dawson V, Kuhar MJ (1994b) Nitric oxide inhibits 3Hglutamate transport in synaptosomes. Synapse 18:21-26

Rabinovich D, Yaniv Shiri P, Alyagor I, Schuldiner O (2016) Nitric oxide as a switching mechanism between axon degeneration and regrowth during developmental remodeling. Cell 164:170-182

Raiteri M, Maura G, Barzizza A (1991) Activation of presynaptic 5hydroxytryptamine1-like receptors on glutamatergic terminals inhibits N-methyl-D-aspartate-induced cyclic GMP production in rat cerebellar slices. JPharmacolExpTher 257:1184-1188

Rivier C (2001) Role of gaseous neurotransmitters in the hypothalamicpituitary-adrenal axis. Ann N Y Acad Sci 933:254-264 
Rivier C (2003) Role of nitric oxide in regulating the rat hypothalamicpituitary-adrenal axis response to endotoxemia. Ann N Y Acad Sci 992:72-85

Rivier C, Shen GH (1994a) In the rat, endogenous nitric oxide modulates the response of the hypothalamic-pituitary-adrenal axis to interleukin-1 beta, vasopressin, and oxytocin. J Neurosci 14:19851993

Rivier C, Shen GH (1994b) In the rat, endogenous nitric oxide modulates the response of the hypothalamic-pituitary-adrenal axis to interleukin-1 $\beta$, vasopressin, and oxytocin. J Neurosci 14:1985-1993

Romero-Grimaldi C, Moreno-López B, Estrada C (2008) Age-dependent effect of nitric oxide on subventricular zone and olfactory bulb neural precursor proliferation. J Comp Neurol 506:339-346

Salehpour M, Khodagholi F, Zeinaddini Meymand A, Nourshahi M, Ashabi G (2017) Exercise training with concomitant nitric oxide synthase inhibition improved anxiogenic behavior, spatial cognition, and BDNF/P70S6 kinase activation in 20-month-old rats. Appl Physiol Nutr Metab 43:45-53

Sales AJ, Hiroaki-Sato VA, Joca SR (2017) Participation of hippocampal nitric oxide synthase and soluble guanylate cyclase in the modulation of behavioral responses elicited by the rat forced swimming test. Behav Pharmacol 28:19-29

Santarelli L, Saxe M, Gross C, Surget A, Battaglia F, Dulawa S, Weisstaub N, Lee J, Duman R, Arancio O, Belzung C, Hen R (2003) Requirement of hippocampal neurogenesis for the behavioral effects of antidepressants. Science 301:805-809

Segovia G, Porras A, Mora F (1994) Effects of a nitric oxide donor on glutamate and GABA release in striatum and hippocampus of the conscious rat. Neuroreport 5:1937-1940

Segovia G, Del Arco A, Mora F (1997) Endogenous glutamate increases extracellular concentrations of dopamine, GABA, and taurine through NMDA and AMPA/kainate receptors in striatum of the freely moving rat: a microdialysis study. J Neurochem 69:14761483

Segovia G, Del Arco A, Mora F (1999) Role of glutamate receptors and glutamate transporters in the regulation of the glutamate-glutamine cycle in the awake rat. NeurochemRes 24:779-783

Seo DO, Rivier C (2001) Microinfusion of a nitric oxide donor in discrete brain regions activates the hypothalamic-pituitary-adrenal axis. J Neuroendocrinol 13:925-933

Silva Pereira V, Elfving B, Joca SRL, Wegener G (2017) Ketamine and aminoguanidine differentially affect Bdnf and Mtor gene expression in the prefrontal cortex of adult male rats. Eur J Pharmacol 815:304 311

Silva M, Aguiar DC, Diniz CR, Guimaraes FS, Joca SR (2012) Neuronal NOS inhibitor and conventional antidepressant drugs attenuate stress-induced fos expression in overlapping brain regions. Cell Mol Neurobiol 32:443-453

Spalding KL, Bergmann O, Alkass K, Bernard S, Salehpour M, Huttner HB, Boström E, Westerlund I, Vial C, Buchholz BA, Possnert G, Mash DC, Druid H, Frisén J (2013) Dynamics of hippocampal neurogenesis in adult humans. Cell 153:X1219-X1227

Spiacci A Jr, Kanamaru F, Guimaraes FS, Oliveira RM (2008) Nitric oxide-mediated anxiolytic-like and antidepressant-like effects in animal models of anxiety and depression. Pharmacol Biochem Behav $88: 247-255$

Srivastava N, Barthwal MK, Dalal PK, Agarwal AK, Nag D, Seth PK, Srimal RC, Dikshit M (2002) A study on nitric oxide, betaadrenergic receptors and antioxidant status in the polymorphonuclear leukocytes from the patients of depression. J Affect Disord 72:4552

Stanford SC, Stanford BJ, Gillman PK (2009) Risk of severe serotonin toxicity following co-administration of methylene blue and serotonin reuptake inhibitors: an update on a case report of post-operative delirium. J Psychopharmacol (Oxf) 24(10):1433-1438
Stanquini LA, Biojone C, Guimaraes FS, Joca SR (2018) Repeated treatment with nitric oxide synthase inhibitor attenuates learned helplessness development in rats and increases hippocampal BDNF expression. Acta Neuropsychiatr 30:127-136

Strasser A, McCarron RM, Ishii H, Stanimirovic D, Spatz M (1994) Larginine induces dopamine release from the striatum in vivo. Neuroreport 5:2298-2300

Sullivan PF, de Geus EJ, Willemsen G, ..., Penninx BW (2009) Genomewide association for major depressive disorder: a possible role for the presynaptic protein piccolo. Mol Psychiatry 14:359-375

Sunico CR, Portillo F, Gonzalez-Forero D, Moreno-Lopez B (2005) Nitric-oxide-directed synaptic remodeling in the adult mammal CNS. J Neurosci 25:1448-1458

Suzuki E, Yagi G, Nakaki T, Kanba S, Asai M (2001) Elevated plasma nitrate levels in depressive states. J Affect Disord 63:221-224

Suzuki E, Yoshida Y, Shibuya A, Miyaoka H (2003) Nitric oxide involvement in depression during interferon-alpha therapy. Int J Neuropsychopharmacol 6:415-419

Swaab DF, Bao A-M, Lucassen PJ (2005) The stress system in the human brain in depression and neurodegeneration. Ageing Res Rev 4:141194

Tanda K, Nishi A, Matsuo N, Nakanishi K, Yamasaki N, Sugimoto T, Toyama K, Takao K, Miyakawa T (2009) Abnormal social behavior, hyperactivity, impaired remote spatial memory, and increased D1mediated dopaminergic signaling in neuronal nitric oxide synthase knockout mice. Mol Brain 2:19

Tang J, Yu W, Chen S, Gao Z, Xiao B (2018) Microglia polarization and endoplasmic reticulum stress in chronic social defeat stress induced depression mouse. Neurochem Res 43:985-994

Thomsen LL (1997) Investigations into the role of nitric oxide and the large intracranial arteries in migraine headache. Cephalalgia 17: 873-895

Thomsen LL, Olesen J (1998) Nitric oxide theory of migraine. Clin Neurosci 5:28-33

Tillmann S, Pereira VS, Liebenberg N, Christensen AK, Wegener G (2017) ZL006, a small molecule inhibitor of PSD-95/nNOS interaction, does not induce antidepressant-like effects in two genetically predisposed rat models of depression and control animals. PLoS One 12:e182698

Tsuchiya T, Kishimoto J, Koyama J, Ozawa T (1997) Modulatory effect of L-NAME, a specific nitric oxide synthase (NOS) inhibitor, on stress-induced changes in plasma adrenocorticotropic hormone $(\mathrm{ACTH})$ and corticosterone levels in rats: physiological significance of stress-induced NOS activation in hypothalamic-pituitary-adrenal axis. Brain Res 776:68-74

Volke V, Wegener G, Vasar E, Rosenberg R (1999) Methylene blue inhibits hippocampal nitric oxide synthase activity in vivo. Brain Res 826:303-305

Volke V, Wegener G, Bourin M, Vasar E (2003) Antidepressant- and anxiolytic-like effects of selective neuronal NOS inhibitor 1-(2trifluoromethylphenyl)-imidazole in mice. Behav Brain Res 140: $141-147$

Volonte C, Apolloni S, Skaper SD, Burnstock G (2012) P2X7 receptors: channels, pores and more. CNS Neurol Disord Drug Targets 11: 705-721

Vorherr T, Knoepfel L, Hofmann F, Mollner S, Pfeuffer T, Carafoli E (1993) The calmodulin binding domain of nitric oxide synthase and adenylyl cyclase. Biochemistry (Mosc) 32:6081-6088

Vos T, Abajobir AA, Abate KH, [...], Murray CJL (2017) Global, regional, and national incidence, prevalence, and years lived with disability for 328 diseases and injuries for 195 countries, 1990-2016: a systematic analysis for the Global Burden of Disease Study 2016. Lancet 390:1211-1259

Wallerath T, Gath I, Aulitzky WE, Pollock JS, Kleinert H, Förstermann U (1997) Identification of the NO synthase isoforms expressed in 
human neutrophil granulocytes, megakaryocytes and platelets. Thromb Haemost 77:163-167

Wegener G, Rujescu D (2013) The current development of CNS drug research. Int J Neuropsychopharmacol 16:1687-1693

Wegener G, Volke V (2010) Nitric oxide synthase inhibitors as antidepressants. Pharmaceuticals 3:273-299

Wegener G, Volke V, Rosenberg R (2000) Endogenous nitric oxide decreases hippocampal levels of serotonin and dopamine in vivo. Br J Pharmacol 130:575-580

Wegener G, Volke V, Harvey BH, Rosenberg R (2003) Local, but not systemic, administration of serotonergic antidepressants decreases hippocampal nitric oxide synthase activity. Brain Res 959:128-134

Wegener G, Harvey BH, Bonefeld B, Muller HK, Volke V, Overstreet DH, Elfving B (2010) Increased stress-evoked nitric oxide signalling in the Flinders sensitive line (FSL) rat: a genetic animal model of depression. Int J Neuropsychopharmacol 13:461-473

Weitzdoerfer R, Hoeger H, Engidawork E, Engelmann M, Singewald N, Lubec G, Lubec B (2004) Neuronal nitric oxide synthase knock-out mice show impaired cognitive performance. Nitric Oxide 10:130 140

Wittchen HU, Jacobi F, Rehm J, Gustavsson A, Svensson M, Jonsson B, Olesen J, Allgulander C, Alonso J, Faravelli C, Fratiglioni L, Jennum P, Lieb R, Maercker A, van Os J, Preisig M, SalvadorCarulla L, Simon R, Steinhausen HC (2011) The size and burden of mental disorders and other disorders of the brain in Europe 2010. Eur Neuropsychopharmacol 21:655-679

Xing G, Chavko M, Zhang LX, Yang S, Post RM (2002) Decreased calcium-dependent constitutive nitric oxide synthase (cNOS) activity in prefrontal cortex in schizophrenia and depression. Schizophr Res 58:21-30

Xiong H, Yamada K, Han D, Nabeshima T, Enikolopov G, Carnahan J, Nawa H (1999) Mutual regulation between the intercellular messengers nitric oxide and brain-derived neurotrophic factor in rodent neocortical neurons. Eur J Neurosci 11:1567-1576

Yazir Y, Utkan T, Aricioglu F (2012) Inhibition of neuronal nitric oxide synthase and soluble guanylate cyclase prevents depression-like behaviour in rats exposed to chronic unpredictable mild stress. Basic Clin Pharmacol Toxicol 111:154-160

Yildiz F, Erden BF, Ulak G, Utkan T, Gacar N (2000) Antidepressant-like effect of 7-nitroindazole in the forced swimming test in rats. Psychopharmacol (Berl) 149:41-44
Yu YW, Chen TJ, Wang YC, Liou YJ, Hong CJ, Tsai SJ (2003) Association analysis for neuronal nitric oxide synthase gene polymorphism with major depression and fluoxetine response. Neuropsychobiology 47:137-140

Yuen EC, Gunther EC, Bothwell M (2000) Nitric oxide activation of TrkB through peroxynitrite. Neuroreport 11:3593-3597

Zaragoza C, Ocampo C, Saura M, Leppo M, Wei XQ, Quick R, Moncada S, Liew FY, Lowenstein CJ (1998) The role of inducible nitric oxide synthase in the host response to Coxsackievirus myocarditis. Proc Natl Acad Sci U S A 95:2469-2474

Zaragoza C, Ocampo CJ, Saura M, Bao C, Leppo M, Lafond-Walker A, Thiemann DR, Hruban R, Lowenstein CJ (1999) Inducible nitric oxide synthase protection against coxsackievirus pancreatitis. J Immunol 163:5497-5504

Zhang G-F, Wang N, Shi J-Y, Xu S-X, Li X-M, Ji M-H, Zuo Z-Y, Zhou ZQ, Yang J-J (2013) Inhibition of the 1-arginine-nitric oxide pathway mediates the antidepressant effects of ketamine in rats in the forced swimming test. Pharmacol Biochem Behav 110:8-12

Zhao M, Chen L, Yang J, Han D, Fang D, Qiu X, Yang X, Qiao Z, Ma J, Wang L, Jiang S, Song X, Zhou J, Zhang J, Chen M, Qi D, Yang Y, Pan H (2018) BDNF Val66Met polymorphism, life stress and depression: a meta-analysis of gene-environment interaction. J Affect Disord 227:226-235

Zhou QG, Hu Y, Hua Y, Hu M, Luo CX, Han X, Zhu XJ, Wang B, Xu JS, Zhu DY (2007) Neuronal nitric oxide synthase contributes to chronic stress-induced depression by suppressing hippocampal neurogenesis. J Neurochem 103:1843-1854

Zhou L, Li F, Xu HB, Luo CX, Wu HY, Zhu MM, Lu W, Ji X, Zhou QG, Zhu DY (2010) Treatment of cerebral ischemia by disrupting ischemia-induced interaction of nNOS with PSD-95. Nat Med 16: 1439-1443

Zhou QG, Zhu LJ, Chen C, Wu HY, Luo CX, Chang L, Zhu DY (2011) Hippocampal neuronal nitric oxide synthase mediates the stressrelated depressive behaviors of glucocorticoids by downregulating glucocorticoid receptor. J Neurosci 31:7579-7590

Zhu XJ, Hua Y, Jiang J, Zhou QG, Luo CX, Han X, Lu YM, Zhu DY (2006) Neuronal nitric oxide synthase-derived nitric oxide inhibits neurogenesis in the adult dentate gyrus by down-regulating cyclic AMP response element binding protein phosphorylation. Neurosci 141:827-836

Zorumski CF, Izumi Y (1993) Nitric oxide and hippocampal synaptic plasticity. Biochem Pharmacol 46:777-785 